\title{
The Effect of Discovery Learning Model on Students Mathematical Understanding Concepts Ability of Junior High School
}

\author{
Jetti H Sinambela*, E. Elvis Napitupulu, Mulyono, Lamtiur Sinambela \\ Post Graduate Program in Mathematics Education, State University of Medan, Medan, Indonesia \\ *Corresponding author: jettisinambela93@gmail.com
}

Received November 05, 2018; Revised December 12, 2018; Accepted December 24, 2018

\begin{abstract}
The purpose of this research is to find out whether there are: (1) the effect of discovery learning on mathematical understanding concepts ability, (2) the interaction between instruction and the prior mathematical ability towards mathematical understanding concepts ability. This research is quasi-experimental research. The population is all seventh grade students of Bina Bersaudara in Medan. Sample was taken by using total sampling technique so that the sample of the research was the seventh grade students then using randomly selected the experimental class was treated with discovery learning and control class with conventional learning. The instrument of the research are the mathematical understanding concepts ability test. Data were analyzed by using two way anova. Based on the results of the analysis obtained the results of the study are: (1) there is the effect of discovery learning model on the mathematical understanding concept ability, (2) there is no interaction between instruction and students prior mathematical ability towards mathematical understanding concepts ability.
\end{abstract}

Keywords: mathematical understanding concept ability, discovery learning

Cite This Article: Jetti H Sinambela, E. Elvis Napitupulu, Mulyono, and Lamtiur Sinambela, "The Effect of Discovery Learning Model on Students Mathematical Understanding Concepts Ability of Junior High School." American Journal of Educational Research, vol. 6, no. 12 (2018): 1673-1677. doi: 10.12691/education-6-12-13.

\section{Introduction}

Mathematics is the basic knowledge needed by students to support their learning success in taking higher education. Even mathematics plays a role in improving the quality of human resources and as a tool to develop other scientific disciplines. Soedjadi [1] said that mathematics education has two major objectives which include (1) formal goals, which put pressure on structuring children's reasoning and the formation character of children and (2) material goals that put pressure on the application of mathematics and ability to solve math problem. Students are expected to be able to find the relationship of various representations of concepts or applying mathematics in other fields or in daily live.

In mathematics, one of the things to consider is mathematical understanding concepts ability. Based understanding mathematics, students are able to solve mathematical problems. Principle Standart of School Mathematics [2] that the purpose of the student learn mathematics is to develop and deepen understanding of mathematic concepts. Then Minarni, Napitupulu, dan Husein [3] that the goal of learning various mathematical concept is in order to perform problem solving, while through problem solving the student developed other kind of mathematical ability such as mathematical comprehension (understanding).
Based on the tests given to students before the research, it shown that the mathematical understanding concepts ability of students is still low, especially in mathematical problem solving. To improve that ability, learning models are needed to support it. Therefore, that the learning process is entire authorited by teacher as the planner, manager and implementer of learning in school. Dimyanti \& Mudjiono [4] said that, "Competent teachers will be better able to create an effective learning environment and will be better able to develop their profession through the use of multi models, methods, strategies, tips, ways and techniques in learning lesson material, so students get results brilliant, both in the form of cognitive, affective and psychomotor domains.

Understanding concept is an ability that becomes the basis for students in doing math. By having the mathematical understand concepts ability, it will facilitate students in problem solving so that students are expected to be able to present problem solving in accordance with their own ideas without having to focus on a form of solution.

According to Gilmore and Bryant [5] that understanding conceptual is the ability to understand concepts, operations and relations in mathematics. According to Duffin and Simpson [6] students have the understanding concepts ability when students are able to (1) explain the concept or be able to re-express what has been communicated. (2) Using concepts in a variety of different situations, and (3) Developing some of the results of a concept. 
Indicators of the understanding concept ability in this study are (1) restating a concept with using self- language, (2) giving examples and not examples of concepts, and (3) applying the concept to problem solving.

Discovery Learning has a good learning concept. According to Hosnan [7], discovery learning is one of the learning models used in modern constructivism approach. In learning discovery students are encouraged to learn on their own, namely through active involvement with concepts and principles. Bruner (Kirschner) [8] recommending minimal guidance was understandable when Bruner proposed discovery learning as an instructional tool because the structures and relations that constitute human cognitive architecture had not yet been mapped.

\section{Research Method}

This research is categorized into quasi-experimental research with a Non Equivalent Postest Only Control Group Design. The population of this study was all students of class VII of the SMP Swasta Bina Bersaudara Medan. The sampling technique used was total sampling technique so that the research sample was class VII students then the experimental class was chosen randomly (class VII-2) given discovery learning and control class treatment (Class VII-1) with conventional learning.

Before the discovery learning model is applied, the teacher gives a test to students to see the prior mathematical ability. When learning takes place, students are given a students' activity sheet to be discussed in each group with instructions from the teacher. After the learning is completed in accordance with what has been planned, students are given a test of the mathematical understanding concepts ability. Then test the data by using the normality test and homogeneity test as the required statistical prerequisites. Then use two-way ANOVA through the version 20 of SPSS program. The statistical model in this study is as follows [9].

$$
Y_{i j k}=\tau+\alpha_{i}+\beta_{j}+(\alpha \beta)_{i j}+\varepsilon_{i j k}
$$

where $\mathrm{i}=1,2,3 ; \mathrm{j}=1,2 ; \mathrm{k}=1,2, \ldots$

with:

$Y_{i j k}$ : score dependent variable (student's

mathematical understanding concept ability)

$\tau$ : average actual score (constant value)

$\alpha_{i}$ : additives effect from PMA-i (high,

medium, and low)

$\beta_{j}$ : additives effect from $\mathrm{j}$-learning

$(\alpha \beta)_{i j}$ : interaction between learning model and

student's prior mathematical ability

$\boldsymbol{\varepsilon}_{k(i j)}$ : k error in treatment combination (ij).

\section{Research Result}

\subsection{Description of Prior Mathematical Ability}

The prior mathematical ability test was used to determine the equality of the sample classes research and to determine the students' mathematical ability which students already had it before the learning process was carried out in this research.

The table above illustrates that the average prior mathematical ability score for each class of the study sample is relatively same. Then grouping of mathematical ability of students (high, medium and low) was formed based on the prior mathematical ability value of students.

Table 1. Statistic of Prior Mathematical Ability (PMA)

\begin{tabular}{|c|c|c|c|c|c|}
\hline Group & PMA & Mean & SD & Min & Max \\
\hline \multirow{3}{*}{ Experiment } & High (4) & 65 & 4,08 & 60 & 70 \\
\cline { 2 - 6 } & Medium (23) & 44,57 & 7,22 & 35 & 55 \\
\cline { 2 - 6 } & Low (5) & 20 & 3,55 & 15 & 25 \\
\hline \multirow{3}{*}{ Control } & High (4) & 62,5 & 5,0 & 60 & 70 \\
\cline { 2 - 6 } & Medium (23) & 44,13 & 6,51 & 35 & 55 \\
\cline { 2 - 6 } & Low (4) & 21,25 & 6,29 & 15 & 30 \\
\hline
\end{tabular}

\subsection{Description of the Test of Mathematical Understanding Concept Ability}

The results of the comprehension test of mathematical concepts give information about the students' mathematical understanding concept ability after being given discovery learning model in the experimental class and to determine the students' ability to understanding concepts after being given conventional learning in the control class.

Table 2. MUCA Average Based on Learning Approach and PMA

\begin{tabular}{|c|c|c|c|c|c|}
\hline Group & PMA & Mean & SD & Min & Max \\
\hline \multirow{4}{*}{ Experiment } & High (4) & 83,75 & 7,5 & 75 & 90 \\
\cline { 2 - 6 } & Medium (23) & 67,61 & 11,19 & 30 & 80 \\
\cline { 2 - 6 } & Low (5) & 47,5 & 18,29 & 37 & 60 \\
\hline \multirow{3}{*}{ Control } & High (4) & 77,5 & 9,57 & 65 & 85 \\
\cline { 2 - 6 } & Medium (23) & 54,57 & 11,17 & 30 & 75 \\
\cline { 2 - 6 } & Low (4) & 30 & 14,14 & 10 & 40 \\
\hline
\end{tabular}

To know the effect of discovery learning on mathematical understanding concept ability, two-way ANOVA statistical analysis was carried out.

Table 3. Two Way Anova Test Result of Mathematical Understanding Concept Ability

\begin{tabular}{|l|c|c|c|c|c|}
\hline \multicolumn{5}{|l|}{ Tests of Between-Subjects Effects } \\
\hline Dependent Variable: understanding concept ability \\
\hline Source & $\begin{array}{c}\text { Type III Sum } \\
\text { of Squares }\end{array}$ & df & $\begin{array}{c}\text { Mean } \\
\text { Square }\end{array}$ & F & Sig. \\
\hline Corrected Model & $10137.570^{\mathrm{a}}$ & 5 & 2027.514 & 16.849 & .000 \\
\hline Intercept & 125230.313 & 1 & 125230.313 & 1040.717 & .000 \\
\hline PMA & 7670.441 & 2 & 3835.220 & 31.872 & .000 \\
\hline Learning & 1265.711 & 1 & 1265.711 & 10.519 & .002 \\
\hline PMA * Learning & 120.975 & 2 & 60.487 & .503 & .608 \\
\hline Error & 6858.859 & 57 & 120.331 & & \\
\hline Total & 248318.750 & 63 & & & \\
\hline Corrected Total & 16996.429 & 62 & & & \\
\hline
\end{tabular}

a. R Squared $=.596($ Adjusted $\mathrm{R}$ Squared $=.561)$ 
Table show that the significance value of the discovery learning model is $0.002<0.05$, it means that there are differences in the understanding concepts ability between students who are given discovery learning and students who are given conventional learning. Hopkins and Glass [10] state that if two sample averages are compared (the average experimental class with the control class average) and the two averages are the same, that means the treatment has no effect. In this case, the average value of the experimental class and control class is different so that the difference can also be interpreted as the influence of the discovery learning model on the students' mathematical understanding concepts ability. So it can be concluded that there is an influence of discovery learning model on the students' mathematical understanding concepts ability.

This is reinforced through the results of research by Hasibuan, Irwan and Mirna [11] in their research on the application of guided discovery methods to mathematical learning, indicating that this model can improve the ability to understand mathematical concepts. Based on his research, it was concluded that the mathematical understanding of students in the class applied to the discovery method was better than the mathematical understanding of students in the class applied to conventional learning.

The high understanding ability of students' mathematical concepts in discovery learning due to it can help students understand easily and discover the mathematical concepts given. Each stage in the discovery learning model contributes to students' mathematical understanding concept ability. Euphony [12] in his research shows that discovery learning can develop all the potential students have when learning.

The learning process with discovery learning model begins with the presentation of several problems that are poured into students' activity sheet that are included with several questions as student guides in problems solving, so students can understand each mathematical concept learned and learning objectives can be achieved and the influence of discovery learning model on mathematical understanding concept ability can also be calculated. The same thing was expressed by Balim [13] that discovery learning model can improve students 'success in learning, can attract students' attention so students become more effective in learning. Thus more students find themselves the concept of subject. So that the discovery learning model is better than conventional learning.

In addition to seeing the influence of learning, ANOVA can also show the interaction between learning and PMA. Table 3 shows that the significance value is $0.608>0.05$ so it can be concluded that there is no interaction between discovery learning and PMA on mathematical understanding concept ability. This means that the difference in the average score of the mathematical understanding concept ability with high, medium and low categories of PMA between those taught with discovery learning and conventional is not significantly different. Therefore the prior mathematical ability and discovery learning do not have a joint effect on improving students' mathematical understanding concept ability. Graphically can be seen in Figure 1 below.

Figure 1 shows that discovery learning is better or more influential in achieving the understanding concept ability because the average score achieved by students in this class is higher than the average score achieved by students in conventional classes. From the difference in scores in groups, it appears that students with low categories benefit more from discovery learning.

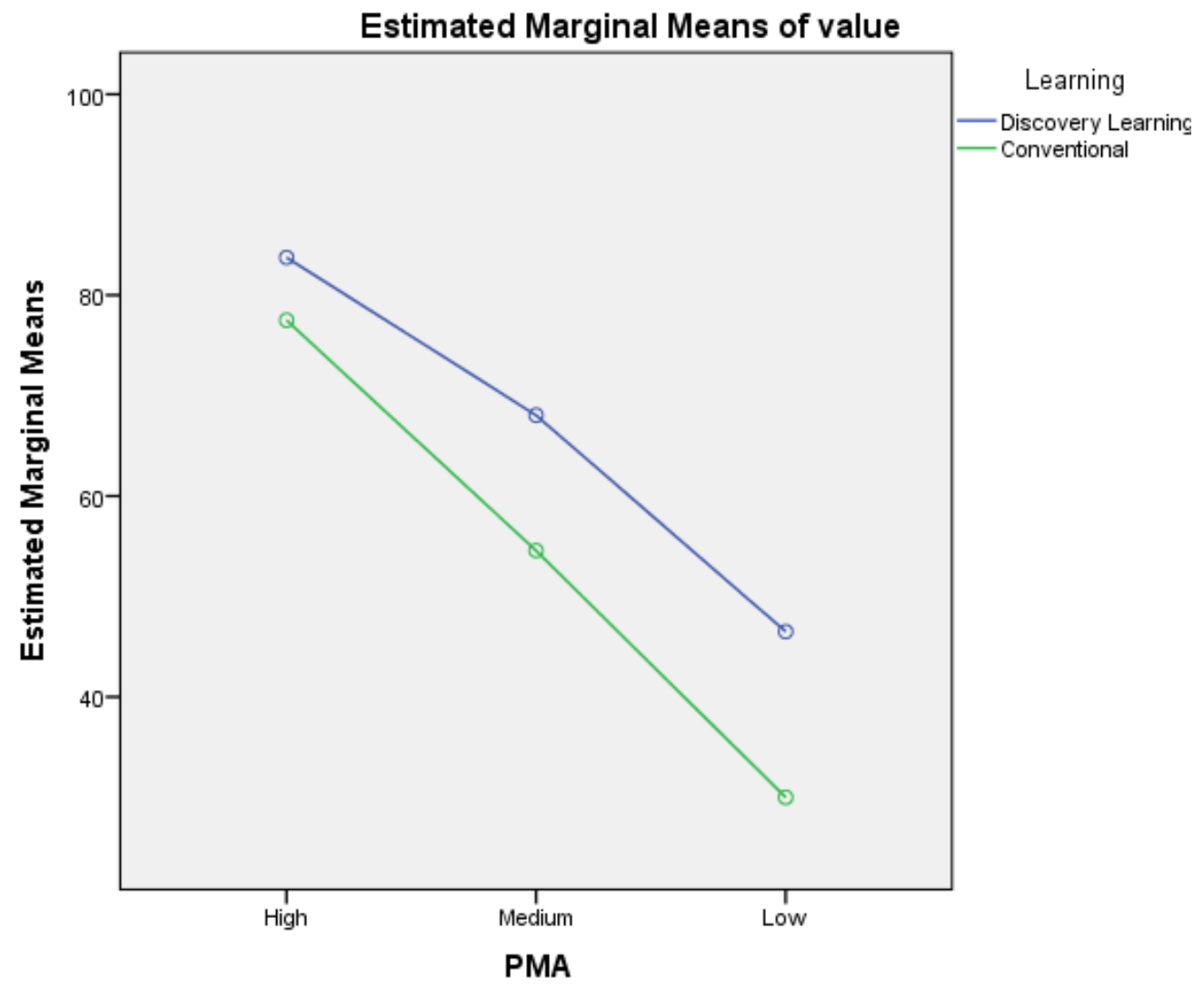

Figure 1. Interaction between Discovery Learning and PMA on Mathematical Understanding Concept Ability 
This is appropriate to the results of research conducted by Pasaribu, Surya and Syahputra [14] who say that there is no interaction between students' prior mathematical ability and learning model towards improving students' mathematical understanding skills. The description of the results of this analysis shows that discovery learning can be used at all levels of prior mathematical ability of students which low, medium and high.

The absence of such interactions may be caused by the grouping of students based on their prior mathematical ability are not describing the actual mathematical ability of the actual students, because the data obtained is only based on giving PMA tests.

\section{Discussion}

Based on the results of the research concluded that there is effect of discovery learning model on the mathematical understanding concept ability of students. This can be seen based on the tests given to students. Judging from students' prior mathematical ability that between students in the experimental class and students in the control class did not have different prior ability. After both the experimental class and the control class were given different learning shows that, the mathematical understanding concept ability of experimental class students who obtain discovery learning is better than the mathematical understanding concept ability of control class students who obtain conventional learning.

This shows the effect of discovery learning model on mathematical understanding concept ability. This is reinforced through the results of research conducted by Hasibuan, Irwan and Mirna [15] in their research on the application of guided discovery methods to mathematics learning, indicating that this model can improve the mathematical understanding concept ability. Based on their research, it was concluded that the mathematical understanding of students in the class applied to the discovery method was better than the mathematical understanding of students in the class applied to conventional learning.

The high mathematical understanding concept ability of students' in discovery learning caused it can to help students easily understand and discover the mathematical concepts given. Each stage in the discovery learning model greatly contributes to students' mathematical understanding concept ability. Euphony [16] in his research shows that discovery learning can develop all the potential students have when learning. So, all stages in the discovery learning model are really applied in the learning process. The phase includes (1) giving stimulation, (2) identifying problems, (3) collecting data, (4) processing data, (5) verification, (6) conclusions.

Minarni, Napitupulu and Husein [17] said the purpose of teaching mathematics is mathematical understanding concepts, describing the relationship between concepts and applying concepts or algorithms in solving problems in a flexible, accurate, efficient and appropriate manner. Minarni and Npitupulu [18] also said that students must have the ability to understand, because understanding can avoid misunderstandings and conflicts. Likewise understanding ability is the most important part of problem solving.

The high value acquisition in the experimental group is due to the learning process with discovery learning model begins with the presentation of several problems which are poured into student activity sheets which are included with several questions as student guides in problem solving so students can understand each of the mathematical concepts learned and learning objectives can be achieved and the effect of discovery learning model on the mathematical understanding concept ability of students can also be known. The same thing was expressed by Balim [19] that discovery learning models can improve students success in learning, can attract students' attention so students become more effective in learning. Thus more students find themselves the concept of subject matter. So that the discovery learning model is better than conventional learning.

In the tests given, it was seen that most students were able to answer questions and use suitable concepts to solve the problem at hand. So, overall students who are given discovery learning have understood the concept and solved the problem well, because students correctly present the concept.

Based on the observation of the author during the learning process with the discovery learning model, it can be seen that students are able to write concepts correctly and are able to explain concepts in their own language. The superiority of discovery learning model is that students will remember more about the material because the training given is no longer as in conventional learning, but given gradually as competed so that the concepts obtained will last longer in the student's memory and the learning gained is more meaningful. Thus, based on the theoretical foundation, relevant research and the results of hypothesis testing and explanation of the findings of the above research can be said that there is the effect of discovery learning models on the mathematical understanding concept ability.

\section{Conclusion}

Based on the results of the analysis of tests of students' mathematical understanding concept ability, the results of the study can be summarized as follows, namely:

1. There is an effect of discovery learning model on the students' mathematical understanding concept ability.

2. There is no interaction between discovery learning model and prior mathematical ability on mathematical understanding concept ability.

\section{References}

[1] Soedjadi, R. 2004. Kiat Pendidikan Matematika di Indonesia. Jakarta: Dirjen Dikti.

[2] National Council of Teacher of Mathematics. 1998. Principles and Standards for School Mathematics. Reston. VA: NCTM.

[3] Minarni, A.; Napitupulu, E. E. \& Husein, R. 2016. Mathematical Understanding and Representation Ability of Publik Junior High School in North Sumatra. Journal on Mathematics Education, 7 (1). 
[4] Dimyati \& Mudjiono. 2006. Belajar dan Pembelajaran, Jakarta: Rineka Cipta.

[5] Gilmore, C. K. \& Bryant, P. 2008. Can Children construct inverse relationship in arithmetic? Evidence for Individual Differences in the Development of Conceptual Understanding and Computational Skills. British Journal of Developmental Psycology, 26, 301-316.

[6] Duffin, J. M. \& Simpson, A. P. 2000. A Search for Understanding. Jurnal of Mathematical Behavior, 18(4): 415-427.

[7] Hosnan, M. 2014. Pendekatan Saintifik dam Kontekstual dalam Pembelajaran Abad 21, Bogor: Ghalia Indonedia.

[8] Kirschner, P. 2006. Why Minimal Guidance During Instruction Does Not Work: An Analysis of the Failure of Constructivist, Discovery, Problem-Based, Experiential, and Inquiry-Based Teaching. Educational Psychologist, 41(2): 75-86.

[9] Syahputra, E. 2016. Statistika Terapan. Medan: Unimed Press.

[10] Glass, G. V \& Hopkins, K. D. 1995. Statistical Methods in Educational and Psychology. USA: A. Simon \& Schuster Company.

[11] Hasibuan, H.; Irwan \& Mirna. 2014. Penerapan Metode Penemuan Terbimbing pada Pembelajaran Matematika Kelas XI IPA SMAN 1 Lubuk Alung. Jurnal Pendidikan Matematika. Vol 3, No. 1, hal. 38-44.

[12] Euphony. 2010. The Effectiveness Of Inductive Discovery Learning in 1:1 Mathematics Classroom. Proceedings of the 18th International Conference on Computers in Education, Malaysia, 743-747.
[13] Balım, A. G. 2009. The Effects of Discovery Learning on Students Success and Inquiry Learning Skills. Eurasian Journal of Educational Research, 35: 1-20.

[14] Pasaribu, E. Z.; Surya, E. \& Syahputra, E. 2016. Peningkatan Kemampuan Pemahaman Matematis Siswa Melalui Model Pembelajaran Penemuan Terbimbing Di MTSN 1 Padangsidimpuan. Paradikma, 9 (2).

[15] Hasibuan, H.; Irwan \& Mirna. 2014. Penerapan Metode Penemuan Terbimbing pada Pembelajaran Matematika Kelas XI IPA SMAN 1 Lubuk Alung. Jurnal Pendidikan Matematika. Vol 3, No. 1, hal. 38-44.

[16] Euphony. 2010. The Effectiveness Of Inductive Discovery Learning in 1:1 Mathematics Classroom. Proceedings of the 18th International Conference on Computers in Education, Malaysia, 743-747.

[17] Minarni, A.; Napitupulu, E. E. \& Husein, R. 2016. Mathematical Understanding and Representation Ability of Publik Junior High School in North Sumatra. Journal on Mathematics Education, 7 (1).

[18] Minarni, A. \& Napitupulu, E. E. 2017. Dveloping Instruction Materials Based on Joyful PBL to Improve Students Mathematical Representation Ability. International Education Studies, 10 (9).

[19] Balım, A. G. 2009. The Effects of Discovery Learning on Students Success and Inquiry Learning Skills. Eurasian Journal of Educational Research, 35: 1-20. 